\title{
Developmental Components of Resting Ventilation Among High- and Low-Altitude Andean Children and Adults
}

\author{
A. ROBERTO FRISANCHO, ${ }^{1 *}$ PATRICIA C. J ULIAO, ${ }^{2}$ \\ VERONICA BARCELONA, ${ }^{2}$ CARMELA E. KUDYBA, \\ GLENDA AMAYO ${ }^{2}$ GRECIA DAVENPORT, ${ }^{2}$ ALICIA KNOWLES, ${ }^{2}$ \\ DANI SANCHEZ,'2 MERCEDES VILLENA, ${ }^{3}$ ENRIQUE VARGAS, ${ }^{3}$ \\ AND RUDY SORIA 3 \\ 1University of Michigan, Ann Arbor, Michigan 48109 \\ 2Undergraduate Partici pants in the NIH-Fogarty Minority I nternational \\ Research Training Program of the Center for Human Growth and \\ Development of the University of Michigan, Ann Arbor, Michigan 48109 \\ II nstituto Boliviano deBiología deAltura, La Paz, Bolivia
}

KEY WORDS development; adaptation; high-altitude hypoxia; ventilation; Aymara; Quechua

\begin{abstract}
This paper evaluates the age-associated changes of resting ventilation of 115 high- and low-altitude Aymara subjects, of whom 61 were from the rural Aymara village of Ventilla situated at an average altitude of $4,200 \mathrm{~m}$ and 54 from the rural village of Caranavi situated at an average altitude of $900 \mathrm{~m}$. Comparison of the age patterns of resting ventilation suggests the following conclusions: 1$)$ the resting ventilation $(\mathrm{ml} / \mathrm{kg} / \mathrm{min})$ of high-altitude natives is markedly higher than that of low-altitude natives; 2 ) the age decline of ventilation is similar in both lowlanders and highlanders, but the starting point and therefore the age decline are much higher at high altitude; 3 ) the resting ventilation that characterizes high-altitude Andean natives is developmentally expressed in the same manner as it is at low altitude; and 4) the resting ventilation ( $\mathrm{ml} / \mathrm{kg} / \mathrm{min}$ ) of Aymara high-altitude natives is between $40-80 \%$ lower than that of Tibetans. AmJ Phys Anthropol 109:295-301, 1999. @ 1999 Wiley-L iss, Inc.
\end{abstract}

Previous studies on the ventilatory characteristics of high-altitude natives were limited to documenting either lung volume (Hurtado, 1964; Frisancho, 1975; Frisancho et al., 1997; Greksa et al., 1985; Droma et al., 1991) or the hypoxic ventilatory re sponse (HVR) (Chiodi, 1957; Severinghaus et al., 1966; Weil et al., 1971; West, 1982; Lefrancois et al., 1968, 1969; Pasquis et al., 1971; Mortola et al., 1990, 1992; Lahiri et al., 1976; Byrne-Quinn et al., 1972; Ge et al., 1994a,b; Hackett et al., 1980; Zhuang et al., 1993; Curran et al., 1995; Beall et al., 1997). However, there is no information about the development of resting ventilation. With this purpose, we compared the age-associated changes in resting ventilation of lowand high-altitude Bolivian Aymara natives.

\section{MATERIALS AND METHODS Study population sites}

The study was conducted in two locations, one at low altitude and the other at high altitude.

High altitude. This study was conducted during J une-J uly 1997 in the rural Aymara village of Ventilla situated in the Bolivian altiplano, $50 \mathrm{~km}$ from the city of La Paz, at an average al titude of $4,200 \mathrm{~m}$.

\footnotetext{
Grant sponsor: NIH-Fogarty Minority International Research Training Program; Grant number: 1T3700035; Grant sponsor: National Science Foundation; Grant number: BNS9107236.

*Correspondence to: Dr. A. Roberto Frisancho, Center for Human Growth and Development, 300 N. Ingalls BIdg., University of Michigan, Ann Arbor, MI 48109-0406. E-mail: arfrisan@umich.edu

Received 22 A pril 1998; accepted 23 March 1999.
} 
Low altitude. This study was conducted during J une-J uly 1998 in the rural Aymara village of Caranavi situated in the Bolivian lowlands, $50 \mathrm{~km}$ from the city of Santa Cruz, at an average altitude of $900 \mathrm{~m}$.

\section{Sample}

The study's sample consisted of 118 subjects ranging in age from 11-35 years, of whom 63 were high-altitude natives and 55 low-altitude natives. To recruit subjects, informal arrangements were made with the community leaders of Ventilla and Caranavi, who invited children and their parents to participate in the study. This study's research team included a physician (R.S.) who was in charge of determining health status and excluding unhealthy individuals. The protocol for this study was approved by a Human Subjects Review Committee at the University of Michigan and the Bolivian Institute of Biology and Altitude (IBBA).

\section{Measurements}

Pulmonary ventilation. The measure ments of pulmonary ventilation were obtained as part of a metabolic study. Resting pulmonary ventilation was measured with a calorimeter (Teem 100, Metabolic Analysis System, AeroSport, Inc., Ann Arbor, MI). This instrument has a built-in pneumotach that takes continuous microsamples of expired air. The procedure includes breathing through a face mask into a pneumotach. The measurements displayed on the calorimeter include: minute-by-minute volume of oxygen consumption $\left(\mathrm{VO}_{2}\right)$, carbon dioxide produced $\left(\mathrm{VCO}_{2}\right)$, ventilatory vol ume, barometric temperature pressure saturation (BTPS) $(\mathrm{VEb})$ in liters per minute, and ventilatory volume, standard temperature pressure and dryness (STPD) (VEs) in liters per minute. A two-point calibration was performed before each day's test: every morning of the study, the calorimeter was calibrated with reference to room air, and a gas mixture $\left(16.0 \% \mathrm{O}_{2}\right.$ and $5.02 \% \mathrm{CO}_{2}$, exactly). It should be noted that the present measurement of ventilation refers to total ventilation (VE, liters/min), which encompasses both dead spaceand alveolar ventilation and is therefore only a crude measure of effective alveolar ventilation.

Finally, the values of ventilation were expressed as liters per minute and further adjusted for body weight as milliliters per kilogram of body weight per minute $(\mathrm{ml} / \mathrm{kg} /$ min).

All volunteers were measured both under fasting and nonfasting conditions. The fasting measurements were made in the morning before breakfast. The nonfasting measurements were made in the afternoon, at least $3 \mathrm{hr}$ after the first measurement. Each subject after the first measurement was given breakfast. The ventilation measured in the morning under fasting conditions was highly correlated ( $r=0.95)$ with the ventilati on obtained in the afternoon under nonfasting conditions. However, because ventilation is, in part, determined by metabolic rate, and metabolic rate increases following a meal, for the present analysis we used only the ventilation obtained under fasting conditions.

After a 10-min resting period, each subject was fitted with a face mask that was connected to the calorimeter while they were sitting and were confortably clothed. The volunteers were instructed to relax and breathe normally. Once a steady breathing state was reached, usually within $5 \mathrm{~min}$, the minute-by-minute measurements were done for an average of $30 \mathrm{~min}$.

Arterial oxygen saturation $\left(\mathrm{SaO}_{2}\right)$. $\mathrm{SaO}_{2}$ was measured continuously with an Omeda Biox 3700 Pulse Oximeter (Ohmeda, Boulder, CO). This instrument updates and displays arterial oxygen saturation $\left(\mathrm{SaO}_{2}\right)$ of hemoglobin and pulse rate (every 4-6 beats). The noninvasi ve photocell sensor was placed on theindex finger (occasionally, when readings were erratic, the sensor was placed on the earlobe). The average of the first and last $5 \mathrm{~min}$ of the readings were recorded. In addition, arterial systolic and diastolic blood pressures were measured manually with a sphygmomanometer before and after the test. The average blood pressures are reported here.

Anthropometric measurements. Standardized measurements of height and weight (Frisancho, 1990; Lohman et al., 1988) were obtained for each participant.

Respiratory function. The forced vital capacity (FVC) was measured using a Vitalograph respirometer (MicroSpirometrics, Inc., 
TABLE 1. Anthropometric and ventilatory characteristics of Andean natives ranging in age from 11-35 years

\begin{tabular}{|c|c|c|c|c|}
\hline \multirow[b]{2}{*}{ Age range } & \multicolumn{2}{|c|}{ Males } & \multicolumn{2}{|c|}{ Females } \\
\hline & $\begin{array}{c}\text { High altitude, } \\
\text { mean } \pm \mathrm{SE}\end{array}$ & $\begin{array}{l}\text { Low altitude, } \\
\text { mean } \pm \mathrm{SE}\end{array}$ & $\begin{array}{l}\text { High altitude, } \\
\text { mean } \pm \mathrm{SE}\end{array}$ & $\begin{array}{c}\text { Low altitude, } \\
\text { mean } \pm \mathrm{SE}\end{array}$ \\
\hline \multicolumn{5}{|l|}{ 11-20 years } \\
\hline $\mathrm{N}$ & 28 & 28 & 16 & 17 \\
\hline Age (years) & $15.3 \pm 0.4$ & $16.5 \pm 0.5$ & $16.2 \pm 0.8$ & $14.6 \pm 0.6$ \\
\hline Height $(\mathrm{cm})$ & $154.1 \pm 2.4$ & $157.5 \pm 2.3$ & $148.5 \pm 1.8$ & $152.0 \pm 1.6$ \\
\hline Weight (kg) & $46.6 \pm 2.1 * *$ & $53.1 \pm 2.3$ & $48.3 \pm 2.3$ & $50.1 \pm 2.4$ \\
\hline BMI $\left(\mathrm{kg} / \mathrm{m}^{2}\right)$ & $19.3 \pm 0.4^{*}$ & $21.0 \pm 0.5$ & $21.7 \pm 0.7$ & $21.5 \pm 0.7$ \\
\hline FVC (liters) & $4.5 \pm 0.2$ & $4.2 \pm 0.2$ & $3.9 \pm 0.2$ & $3.7 \pm 0.1$ \\
\hline $\mathrm{FVC}(\mathrm{ml} / \mathrm{cm})$ & $28.9 \pm 1.2^{* *}$ & $26.2 \pm 1.0$ & $26.8 \pm 1.0 * *$ & $25.3 \pm 0.8$ \\
\hline $\mathrm{SaO}_{2}(\%)$ & $90.8 \pm 0.6^{*}$ & $97.9 \pm 0.3$ & $90.9 \pm 0.6 *$ & $96.9 \pm 0.4$ \\
\hline Resting ventilation (liter/min) & $13.6 \pm 0.4^{*}$ & $8.5 \pm 0.6$ & $11.6 \pm 0.3^{*}$ & $9.7 \pm 0.4$ \\
\hline Resting ventilation $(\mathrm{ml} / \mathrm{kg} / \mathrm{min})$ & $305.9 \pm 13.8^{*}$ & $170.1 \pm 18.3$ & $249.9 \pm 14.7 * *$ & $215.3 \pm 7.7$ \\
\hline \multicolumn{5}{|l|}{$21-35$ years } \\
\hline $\mathrm{N}$ & 7 & 34 & 12 & 12 \\
\hline Age (years) & $26.7 \pm 1.7$ & $27.7 \pm 0.8$ & $27.5 \pm 1.7$ & $26.6 \pm 1.5$ \\
\hline Height $(\mathrm{cm})$ & $162.2 \pm 1.7$ & $164.9 \pm 1.0$ & $147.7 \pm 1.1$ & $150.5 \pm 1.5$ \\
\hline Weight (kg) & $60.7 \pm 2.1$ & $64.4 \pm 1.2$ & $49.7 \pm 1.2^{*}$ & $61.6 \pm 3.0$ \\
\hline BMI $\left(\mathrm{kg} / \mathrm{m}^{2}\right)$ & $23.1 \pm 0.7$ & $23.7 \pm 0.4$ & $22.8 \pm 0.6^{*}$ & $27.1 \pm 1.0$ \\
\hline FVC (liters) & $5.4 \pm 0.2$ & $4.8 \pm 0.1$ & $3.8 \pm 0.1$ & $3.7 \pm 0.1$ \\
\hline $\mathrm{FVC}(\mathrm{ml} / \mathrm{cm})$ & $33.0 \pm 1.1^{* *}$ & $29.2 \pm 0.8$ & $26.0 \pm 0.6$ & $24.8 \pm 0.8$ \\
\hline $\mathrm{SaO}_{2}(\%)$ & $91.7 \pm 1.1^{*}$ & $97.9 \pm 0.3$ & $91.4 \pm 0.7^{*}$ & $97.3 \pm 0.3$ \\
\hline Resting ventilation (liter/min) & $14.2 \pm 0.4^{*}$ & $8.9 \pm 0.5$ & $11.1 \pm 0.5$ & $11.3 \pm 0.7$ \\
\hline Resting ventilation $(\mathrm{ml} / \mathrm{kg} / \mathrm{min}$ ) & $232.3 \pm 7.3 *$ & $142.0 \pm 8.2$ & $222.1 \pm 7.5^{*}$ & $185.5 \pm 8.6$ \\
\hline
\end{tabular}

$* P<0.01$.

$* * \mathrm{P}<0.05$

Auburn, ME). The respirometer was adjusted for changes in room temperature beforeeach measurement. The subjects were asked to inhale as completely as possible and then exhale to the maximum in one continuous motion. These respirometric measurements were repeated three times, and the highest of the threevalues was recorded.

\section{Analysis}

The ventilations and FVC were adjusted for body size. The ventilations were adjusted for body weight and expressed as $\mathrm{ml} / \mathrm{kg} / \mathrm{min}$, while theFVC were adjusted for body height and expressed as $\mathrm{ml} / \mathrm{cm}$. All analyses were performed using Statview 5.0 (SAS I nstitute Inc., Cary, NC). The statistical significance of differences in anthropometric and ventilation variables between high- and low-altitude samples was assessed by an analysis of variance test applied separately to each sex and age group. The age trends in resting ventilation were analyzed using regression equations, whereby age was the independent variable and resting ventilation was the dependent variable. The statistical significance of differences in slopes of resting ventilation values were assessed by twosamplet-test.

\section{RESULTS}

Table 1 gives the mean values for the anthropometric and respi ratory data. Among youth, the high-altitude subjects tended to be smaller in body size than their counterparts from low al titudes. On the other hand, the high-altitude boys and girls tended to have systematically higher values of forced vital capacity than the low-altitude youths. Similarly, the arterial oxygen saturation was significantly lower at high altitude. In contrast, from the youngest age measured, 11 years, to the age of 20 years, the resting ventilation, especially when expressed as $\mathrm{ml} / \mathrm{kg} / \mathrm{min}$, was significantly higher among the high-al titude than the low-altitude subjects. Similar differences were observed among adults in terms of arterial oxygen saturation and resting ventilation.

Observation of the individual data indicates that ventilation declines from 11 years (the youngest age measured) until about age 20 years, but thereafter remains unchanged in both populations. Hence, the age-trend analysis excludes those over age 20 years. As shown in Figures 1 and 2 , theage-associated decline in resting ventilation in both males and females follows the same pattern at low 


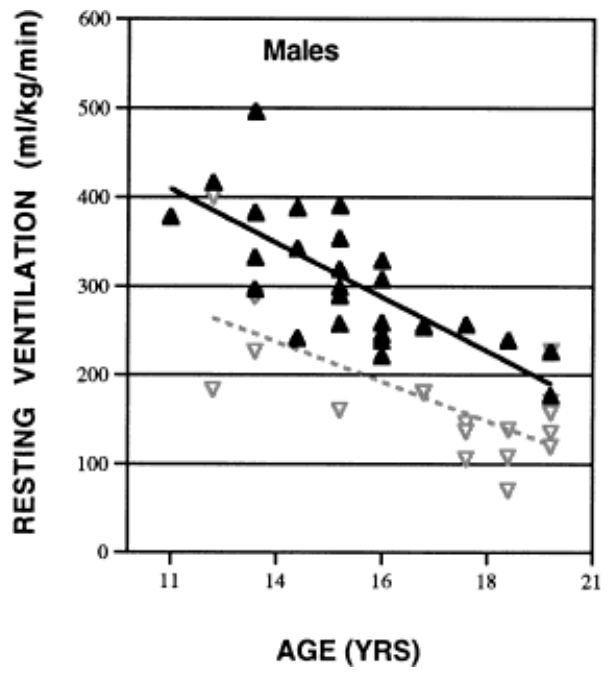

$\Delta \quad$ High Altitude $y=-24.4 x+677.7$

$\nabla \quad$ Low Altitude $y=-17.7 x+476.5$
Fig. 1. Relation of resting ventilation and age among highaltitude Aymara native males. Both at high and low altitude, the age-associated decline in resting ventilation follows the same pattern.

Fig. 2. Relation of resting ventilation and age among highaltitudeAymara native females. Both at high and low altitude, the age-associated decline in resting ventilation follows the same pattern.

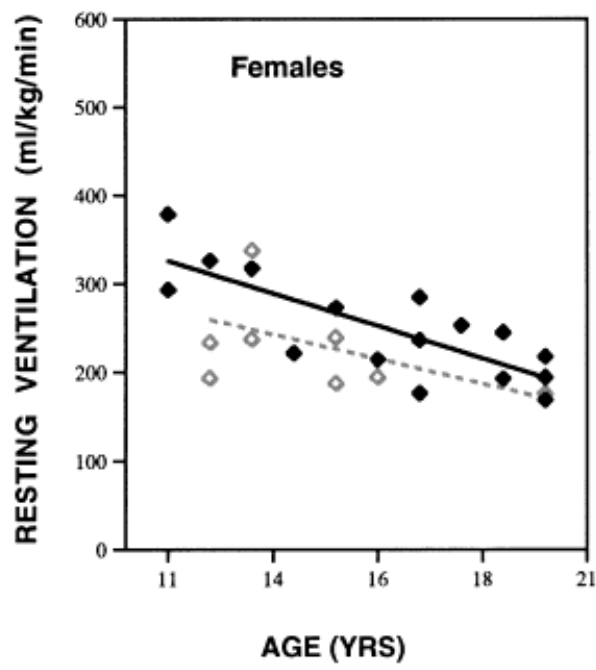

- High Altitude $y=-14.7 x+487.7$

- Low Altitude $y=-11.1 x+392.8$ altitude and high altitude. However, the per-year rate of decline of ventilation as indicated by the difference in slope is higher at high altitude than at low altitude. At high altitude in males, the ventilation declined by approximately $24 \mathrm{ml} / \mathrm{kg} / \mathrm{min}$ per year, which is significantly larger than the 18 $\mathrm{ml} / \mathrm{kg} / \mathrm{min}$ ded ine at low al titude $(\mathrm{P}<0.05)$. In females at high altitude, the ventilation declined by about $15 \mathrm{ml} / \mathrm{kg} / \mathrm{min}$, which is again significantly higher than the $11 \mathrm{ml} / \mathrm{kg} /$ min decline at low altitude $(P<0.05)$ (Fig. 2). The age decline of ventilation is similar in both lowlanders and highlanders, but the starting point and therefore the age change are much higher at high altitude. In contrast, in adulthood, there was no statistically significant age-associated decrease in ventilation in either the high- or lowaltitude population samples.

\section{DISCUSSION}

This is the first study that documents the development of resting ventilation at high and low altitudes. Furthermore, it demonstrates the age-associated decline in resting ventilation is similar at high and low altitudes. The only difference is that the resting ventilation starts from a high point at high altitude, but the rate of decline per 
Fig. 3. Comparison of age-associated dedine of resting ventilation among highaltitude Aymara compared to high-altitude Quechua natives re ported by Sime(1973). Note that the dedine in resting ventilation among high-altitude Quechua natives from Peru is almost identical to that observed among high-altitude Aymara from Bolivia.

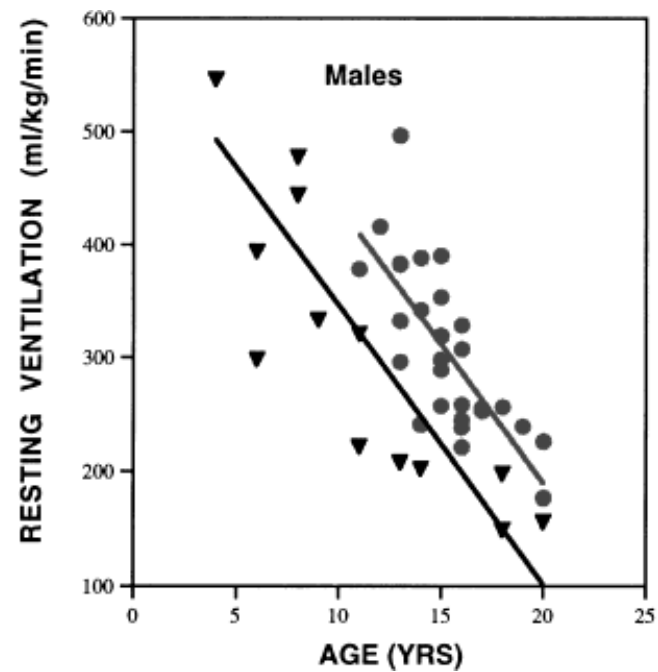

- High Altitude Aymaras from Bolivia $y=-24.4 x+677.7$

High Altitude Quechuas from Peru $y=-24.4 x+590.4$

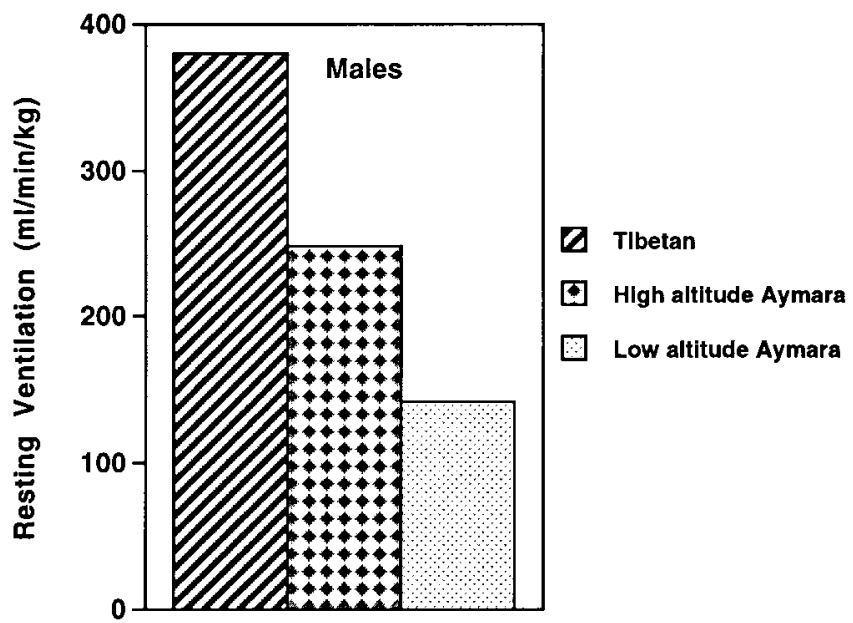

Fig. 4. Comparison of resting ventilation of Aymara and of Tibetan adult males reported by Beall et al. (1997). The Aymara have significantly lower resting ventilation than the Tibetans, but the highaltitude Aymara have higher ventilation than the low-altitudeAymara. year is quite similar in both locations. The age-associated decline in resting ventilation at high altitude, as shown in Figure 3, is similar to the findings reported by Sime (1973) for high-altitude Quechua samples. Therefore, one can conclude that the resting ventilation that characterizes high-altitude Andean natives is developmentally expressed in the same manner as it is at low al titude (Cotes, 1965).

It should benoted that for most physi ological and anthropometric evaluations of highlanders and lowlanders, low altitude is the frame of reference. F or ventilation, however, the frame of reference has always been lowland migrants to high altitude, who tend to have higher ventilation than highland natives. Hence, Andean highlanders are described as having a low hypoxic ventilatory response (Chiodi, 1957; Severinghaus et al., 1966; Weil et al., 1971; West, 1982; Lefrancois et al., 1968; Pasquis et al., 1971; Mortola et al., 1990, 1992; Lahiri et al., 1976; Byrne-Quinn et al., 1972; Beall et al., 1997). However, the present study demonstrates that resting ventilation of Andean highaltitude natives is greater than that of lowlanders at low-altitude.

Several studies have demonstrated that Tibetans have a higher HVR than Andeans (Zhuang et al., 1993; Curran et al., 1995). The ventilation for high-altitude Aymara 


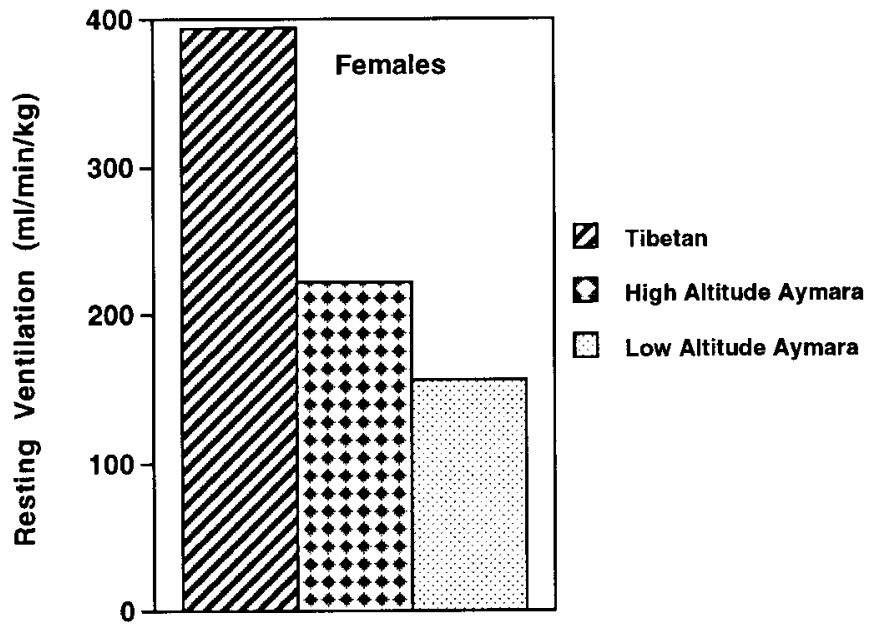

Fig. 5. Comparison of resting ventilation of Aymara and Tibetan adult females reported by Beall et al. (1997). The Aymara have significantly lower resting ventilation than the Tibetans, but the high-altitude Aymara have higher ventilation than the low-altitude Aymara. adults is quitesimilar to the values reported for other Aymara high-altitude samples (Beall et al., 1997), and as illustrated in Figures 4 and 5, the Andean high-altitude natives have a lower resting ventilation than high-altitudeTibetans.

The present findings also confirm that high-altitude natives tend to have higher forced vital capacity when expressed per unit of body size $(\mathrm{ml} / \mathrm{cm})$, which agrees with previous studies (Hurtado, 1964; F risancho, 1975; Frisancho et al., 1997; Greksa et al., 1985; Droma et al., 1991). The present findings also confirm that the arterial oxygen saturation is significantly lower at high altitude than at low altitude.

In summary, the present findings suggest that the resting ventilation that characterizes high-al titudeAndean natives is developmentally expressed in the same manner as it is at low altitude. Furthermore, it confirms that Andean high-altitude natives have a lower resting ventilation than high-altitude Tibetans.

\section{ACKNOWLEDGMENTS}

We thank the administrators, teachers, parents, and especially the children of Escuela Rural de Ventilla and Caranavi, Bolivia. We al so thank Mrs. Ana Maria Alarcon and Cristina Gonzales, laboratory technicians of the Department of Respiratory Physiology of Instituto Boliviano de Altura (IBBA), for their expert assistance. I also thank Stanley M. Garn for his insightful comments. This work was supported in part by NIH-Fogarty Minority International Research Training grant $1 T 3700035$ to the Center for Human Growth and Development of the University of Michigan, and by National Science Foundation grant BNS9107236.

\section{LITERATURE CITED}

Beall CM, Strohl K, Blangero J, Williams-Blangero S, Brittenham GM, Goldstein MC. 1997. Quantitative genetic analysis of arterial oxygen saturation in Tibetan highlanders. Hum Biol. 69:597-604.

Byrne-Quinn E, Sodal IE, Weil J V. 1972. Hypoxic and hypercapnic ventilatory drives in children native to high altitude. J Appl Physiol 32:44-46.

Chiodi H. 1957. Respiratory adaptations to chronic high-altitudehypoxia. J Appl Physiol 10:81-87.

Cotes J E. 1965. Lung function. Philadel phia: Blackwell Scientific Publications. p 1-54.

Curran LS, Zhuang J, Droma T, Land L, Moore LG. 1995. Hypoxic ventilatory responses in Tibetan residents of $4400 \mathrm{~m}$ compared with $3658 \mathrm{~m}$. Respir Physiol 100:223-230.

Droma T, McCullough RG, McCullough RE, Zhuang J, Cymerman A, Sun S, Sutton J R, Moore LG. 1991. Increased vital capacity and total lung capacities in Tibetan compared to Han residents of Lhasa $(3,658$ m). AmJ Phys Anthropol 86:341-351.

Frisancho AR. 1975. Functional adaptation to highaltitude hypoxia. Science 187:313-319.

Frisancho AR. 1990. Anthropometric standards for the assessment of growth and nutritional status. Ann Arbor: Michigan Press. p 43.

Frisancho AR, Frisancho HG, Albalak R, Villena M, Vargas E, Soria R. 1997. Devel opmental, genetic and environmental components of lung volumes at high altitude. AmJ Hum Biol 9:191-203.

Ge R, Qiuhong C, Lungao H, Hailing L. 1994a. Characteristics of hypoxic ventilatory response in Tibetans living at moderate and high altitudes. Chin J TubercuIosis Respir Dis 17:364-366, 388. 
Ge RL, Chen QH, Wang LH, Gen D, Yang P, Keishi K, Fujimoto K, Matsuzawa Y, Yoshimura K, Takeoka M, Kobayashi T. 1994b. Higher exercise performance and lower $\mathrm{VO}_{2}$ in Tibetan than $\mathrm{Han}$ residents at 4,700 m altitude. J Appl Physiol 77:684-691.

Greksa LP, Spielvogel H, Paredes-Fernandez L. 1985 Maximal exercise capacity in adolescent European and Amerindian high-altitude natives. Am J Phys Anthropol 67:209-216.

Hackett PH, Reeves J T, Reeves CD, Grover RF, Rennied D. 1980. Control of breathing in sherpas at low and high altitude. J Appl Physiol 49:374-377.

Hurtado A. 1964. Animals in high altitudes: resident man. In: Dill DB, editor. Handbook of physiology. Section 4: adaptation to the environment. Washington, DC: American Physiological Society. p 843-859.

Lahiri S, Delaney RG, Brody J S, Simpser M, Velasquez T, Motoyama EK, Polgar C. 1976. Relative role of environmental and genetic factors in respiratory adaptation to high altitude. Nature 261:133-135.

Lefrancois R, Gautier H, Pasquis P, Vargas E. 1968. Ventilatory oxygen drive in acute and chronic hypoxia. Respir Physiol 4:217-228.

Lefrancois R, Gautier H, Pasquis P, Vargas E. 1969 Factors controlling respiration during muscular exercise at altitude. Fed Proc 28:1296-1300.

Lohman TG, Roch AF, Martorell R, editors. 1988. Anthropometric standardization reference manual. Champaign, IL: Human Kinetics Books. p 1-177.

M ortola J P, Rezzonico R, Fisher J T, Villena-Cabrera N Vargas E, Gonzales R, Pena F. 1990. Compliance of the respiratory system in infants born at high altitude. Am Rev Respir Dis 142:43-48.

Mortola J P, Frappell PB, Frappell DE, Villena-Cabrera N, Villena-Cabrera M, Pena F. 1992. Ventilation and gaseous metabolism in infants born at high altitude, and their responses to hyperoxia. Am Rev Respir Dis 148:1206-1209.

Pasquis P, Cevaer AM, Coudert J , Leroy J, Guatier H, Lefrancois R. 1971. Stimulus ozygene de la ventilation chez I'homme au cours de sejours prolongés à haute altitudes. J Phyiol (Paris) 63:261-262.

Severinghaus W, Bainton CR, Carcelen A. 1966. Respiratory insensitivity to hypoxia in chronically hypoxic man. Respir Phys 1:308-334.

Sime F. 1973. Ventilacion humana en hipoxia cronica: etiopatogenia de la enfermedad de monge o desadaptacion cronica a la altura. D.Sc. thesis. Lima: Universidad Peruana Cayetano Heredia. p 1-97

Weil J V, Byrne-Quinn E, Sodal IE, Filley GF, Grover RF. 1971. Acquired attenuation of chemoreceptor function in chronically hypoxic man at high altitude. J Clin Invest 50:186-195.

West J B. 1982. Respiratory and circulation control at high altitudes. J Exp Biol 100:147-157.

Zhuang J , Droma T, Sun S, J anes C, McCullough RE, McCullough RG, Cymerman A, Huang SY, Reeves J T, Moore LG. 1993. Hypoxic ventilatory responsiveness in Tibetan compared with $\mathrm{H}$ an residents of $3,658 \mathrm{~m}$. J Appl Physiol 74:303-311. 